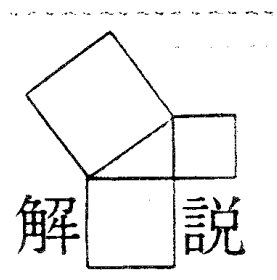

\title{
低乱風洞の設計と性能
}

\section{Design and Performance of a Low-Turbulence Wind Tunnel}

\author{
藤 英 覚*，小林 陵
Hidesato ITO $_{\text {Ryöji }}$ KOBAYASHI
}

Key Words: Fluid Mechanics, Flow Measurement, Wind Tunnel, Turbulence, Boundary Layer

\section{1.まえがき}

風洞の設計は, 流体工学の進歩に伴い最新の知 識を取り入れて行われてきた。気流の乱れ強さが 境界層の層流から乱流への遷移に著しい影響を及 沽すこと，したがって物体の流体力学的特性が一 様流の乱れ強さのいかんによって甚だしく変化 することが明らかとなり，また一方において Tollmien-Schlichting 波の発見により, 遷移現象 の解明に低乱風洞の果たす重要性が認識されるに 及んで, 多目的の一般用低速風洞においても, 風 洞自身が作り出す気流の乱れが測定部で極めて少 ない，いわゆる低乱風洞を指向する傾向が強まっ ている。また，測定部が低乱流であること以外に， 風速分布が一様であること，低騒音であることな どが要求される。

本文は, 最近の低乱風洞の設計方法を解説的に 述べ，つぎその設計方法に基ついて製作された

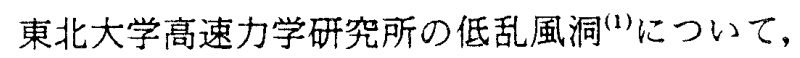
風洞各部の性能を測定した結果 ${ }^{(2)}$ の概略を示し て，低乱流が測定部にいかにして実現したかを述 べ,今後の風洞設計に対し有用な指針を提供しょ うとするものである。

\section{2. 低乱風洞の設計方法}

\section{$2 \cdot 1$ 整流部金網}

$2 \cdot 1 \cdot 1$ 金網による乱強さの減衰風洞測 定部に一様な風速分布と低乱流を実現するために

" 正員, 東北大学高速力学研究所 (下 980 仙台市片平 2-1-1)。

*正員, 東北大学工学部( 7980 仙台市荒巻字青菜)。

日本機械学会誌 第89巻第808号
は，その上流の整流部金網の選択が重要である。 Dryden-Schubauer $^{(3)}$ によれば，1枚の金網の抵 抗係数を $K\left[=\Delta p /\left(\rho U_{s}{ }^{2} / 2\right), こ こ に \Delta p\right.$ は金網 による圧力降下, $\rho$ は流体の密度, $U_{s}$ は整流部の 風速了とするとき，その金網を通過することによ り,気流の乱れ強さは $(1+K)^{-1 / 2}$ 倍に隇衰し, 同 一の抵抗係数を有する金網 $n$ 枚を通過すること による乱れ強さ $U^{\prime} / U$ の減衰は,

$$
\frac{U_{s}^{\prime}}{U_{s}}=\left(\frac{1}{1+K}\right)^{n / 2} \frac{U_{h}^{\prime}}{U_{h}}
$$

で与えられる.ここに $U^{\prime}=\left[\left(\overline{u^{\prime 2}}+\overline{v^{2}}+\overline{w^{\prime 2}}\right) / 3\right]^{1 / 2}$, $u, v^{\prime}, w^{\prime}$ は変動速度の $x, y, z$ 成分の瞬時值, 添字 $s$ は気流が $n$ 枚の金網を通過した後の状態 を，添字 $h$ は $n$ 枚の金網の上流の状態を表す。た だし上流より下流に至る流路断面積は一定で, $U_{s}$ $=U_{h}$ であるとする.なお式（1）は，金網のメッ シュは非常に細かく，金網自身は下流に気流の乱 れを作り出さないことを仮定している．金網の抵 抗係数 $K に は, W i e g h a r d t の$ 式(4) がある.

$2 \cdot 1 \cdot 2$ 金網による非一様速度成分の減衰 気流が金網を通過することによる時間平均速度成 分の一様化は, Taylor-Batchelorの式(5)によっ て推算できる。主流方向成分の一様化は速やかで あるが，垂直方向成分の減衰はかなり遈い.

$2 \cdot 1 \cdot 3$ 整流部金網の設計整流部金網は, 流 路全面にわたつて継ぎ目がないこと，メッシュが 均一であることのほかに, 開口面積比 $\beta>0.57 て ゙$ あることが要求される.何となれば, $\beta$ が 0.57 よ り小さければ，金網の細孔をよぎる流れが不安定 となり，個々の小さい噴流が合体して次第に大き
昭和 61 年 3 月 
な不規則な嘪流に成長するためである(6). 低速風 洞の整流部金網に洨 16 メッシュ, 線径 $0.38 \mathrm{~mm}$, $\beta=0.58$, 風速 $3.6 \mathrm{~m} / \mathrm{s}$ で $K=1.6$ 程度の織金網を $4 \sim 5$ 枚用いることが推奖されている(6).また, 金 網自身によってその下流側に発生する乱れを極力 隇少するため，最終金網に洔に目の細かい金網 の使用が推奖される、なお，金網の針金から出る 後流が隇衰した後に気流が次の金網に流入するた めには，金網間隔は線径の 500 倍にとれば十分で ある ${ }^{(6)}$.

$2 \cdot 2$ 八ニカム 八ニカ厶は流路軸方向の時 間平均の風速分布を一様ならしめ，あわせて流路 軸に直角方向の時間平均速度成分を減少させるか ら，上流側の旋回流と大きなスケールの乱れを除 く効果を持つ(6) (8). しかし，八二カ厶自身は小さ いスケールの乱れを作り出すので，その下流はか なりの乱れ強さとなる ${ }^{(2)(9)}$ ，八ニカムの流路軸方 向の長さはセルの直径の 6 倍ないし 8 倍が普通で ある(6). 航空機のサンドイッチ構造に使用するア ルミニウム・ハニカムは, 整流部八ニカムとして も使用できるる(1)(6)(9).

\section{$2 \cdot 3$ 収縮ノズル}

$2 \cdot 3 \cdot 1$ 乱れ強さの減衰気流乱れによる変

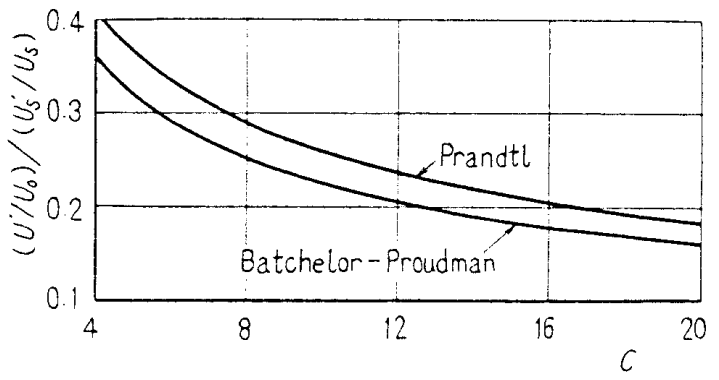

図 1 収縮ノズルによる乱強さの減衰

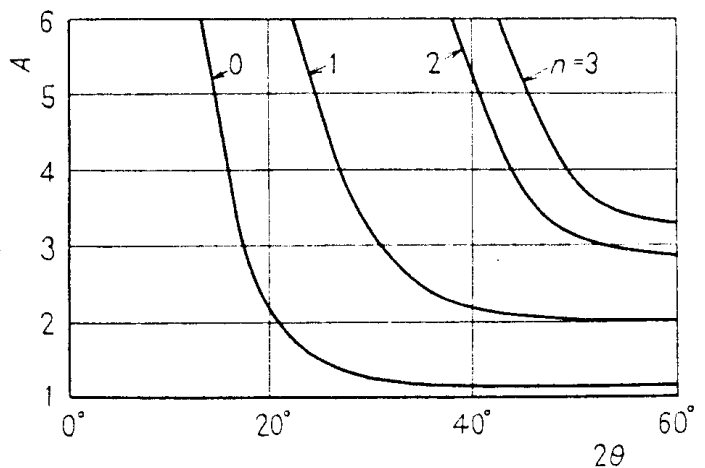

図 2 頂角 $2 \theta$, 面積比 $A$ の広角度ディフューザに必 要な金網の枚数 $n$, 各曲線の左側が安全領域(9)
動速度成分を，ノズルの入口で $u_{s}^{\prime}, v_{s}^{\prime}, w_{s}^{\prime}$, 出 口で $u^{\prime}, v^{\prime}, w^{\prime}$ とし, $\mu_{c}=\overline{u^{\prime 2}} / \overline{u_{s}^{2}}, \nu_{c}=\left(\overline{v^{\prime 2}}+\overline{w^{\prime 2}}\right) /$ $\left(\overline{v_{s}^{\prime 2}}+\overline{w_{s}^{\prime 2}}\right)$ とおく. Batchelor-Proudman ${ }^{(10)} に$ よれば，軸対称收縮ノズルで上流が等方性乱れの とき，非粘性，線形近似のもとに， $\mu_{c}$ およで $\nu_{c}$ 注 それぞれつぎの式で与えられる。

$$
\mu_{c}=\frac{3}{4 c^{2}}\left[\log _{e}\left(4 c^{3}\right)-1\right], \nu_{c}=\frac{3}{4} c
$$

ここに, $c\left[=\left(D_{s} / D\right)^{2}, D_{s}\right.$ は上流側， $D$ は下流側 直径了は収縮ノズルの絞り面積比である。

いま,ノズル出口の乱片大きさを $U^{\prime}$, 時間平 均の風速を $U_{0}$ とすれば, 連続の条件式 $U_{0}=c U_{s}$ を考慮して，ノズル入口の乱れ強さ $U_{s}^{\prime} / U_{s}$ と出 口の乱れ強さ $U^{\prime} / U_{0}$ との関係は,

$$
\frac{U^{\prime}}{U_{0}}=\frac{1}{c}\left(\frac{\mu_{c}+2 \nu_{c}}{3}\right)^{1 / 2} \frac{U_{s}^{\prime}}{U_{s}}
$$

となる。式（2）を用いて式（3）加求めた乱れ 強さの減衰を, 面積比 $c$ に対して図 1 に示す。図 中には参考のためPrandt1 ${ }^{(11)(12)}$ の結果も示して ある。cが大きいほど乱れの減衰量は大になるこ とがわかる，以上は，非粘性を仮定した理論であ るが, Hussain-Ramjee ${ }^{(13)}$ の実験も，収縮ノズルに よる気流乱れの減衰は，境界層部分を除けば主と して面積比 $c$ に依存し，ノズルの形状によらない ことを示している.図 1 から, $c$ を大きくすること のみによっては低乱流の実現は無理であり，整流 部において織金網の使用などによって，気流の乱 れをあらかじめ所要の值まで減少させておく必要 のあることがわかる。

$2 \cdot 3 \cdot 2$ 非一様速度成分の減衰 気流の非一 様な速度分布は収縮ノズルを通過することによっ

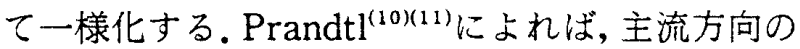
非一様速度成分と主流速度の比は $c^{2}$ に逆比例し て速やかに減衰するが，主流に垂直な速度成分と 主流速度の比は $\sqrt{c} に$ 逆比例して徐々に減少す る.

$2 \cdot 3 \cdot 3$ 収縮ノズルの形状 所要の測定部寸 法に対し収縮ノズルの面積比 $c$ を大きく選ぶと 整流部の断面積が増加するので，必要以上に大き な面積比は避けるべきであって， $c=12 \sim 16$ 程度 が推奨される ${ }^{(6)}$. 与えられた形状の軸対称ノズル を通るポテンシャル流れを解析する理論は, 従来 数多く提案されている ${ }^{(14) \sim(17)}$. 有限な長さの収縮 


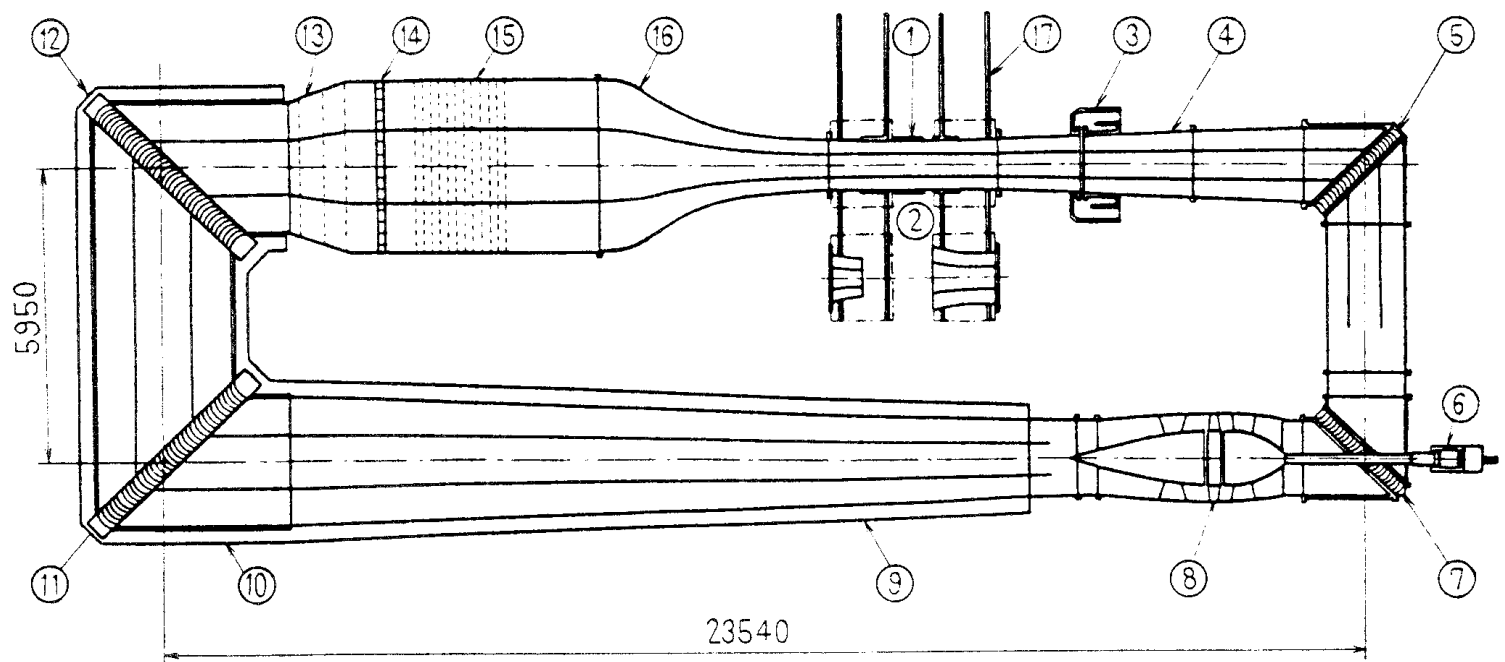

(1)：密閉形測定部 (2): 開放形測定部 (3)：ブリーザおよび消音器 (4)：第1ディフューザ (5): 第 1偏流部 (6): 直流電動機 (7): 第 2 偏流部 (8): 軸流送風機 (9): 第 2 ディフューザ (1D)：コンクリートダクト (11)：第 3 偏流部 (12)：第 4 偏流部 (13)：広角度ディフューザ (14)：八二カム (15)：整流部金網 (16)：収縮ノズル (10)：測定部交換用レール 図 3 東北大学高速力学研究所低乱風洞

ノズルにおいては，ノズル壁面の入口と出口付近 に局所的に減速領域が生ずることは避けられない から，ノズル壁面に沿う圧力分布㧍よび境界層の 成長とはく離の可能性の有無の検討が必要であ $る^{(37)}$ 。

\section{$2 \cdot 4$ ティフューザ}

$2 \cdot 4 \cdot 1$ 第 1 扔よび第 2 ディフューザ ディ フューザにおける流れのはく離は測定部の流れに 激しい非定常性をもたらす ${ }^{(18)}$ から，その頂角およ び面積比の選定は重要である ${ }^{(6)}$. 風洞用ディフュ 一ザの全頂角は $5^{\circ}$ が推奖されている(6)。測定部の すぐ下流に設ける第 1 ディフューザの面積比は 2 ないし 2.5 ，第 2 ディフューザは 3 にとられる ${ }^{(6)}$ 。 第 1 ディフューザ入口にうず発生器(6)(19)を設けて ディフューザ内の流れを安定にする方法もある。

$\mathbf{2} \cdot \mathbf{4} \cdot 2$ 広角度ディフューザ 風洞の全長を 短縮し，あわせて整流部の断面積を大にするため, 整流部の上流に 1 〜 枚の織金網を有する広角度 ディフューザを設ける場合が多い．頂角が大きい ので, 流れのはく離が生じないように注意深い設 計が必要である。図 2 は，過去に各国で製作され た多数の広角度ディフューザを参考にして，面積 比 $A$ および全頂角 $2 \theta$ に対する金網の下限枚数の 推奨值を与えている ${ }^{(9)}$ 。実線の左側が安全領域で ある。上記金網の抵抗係数の和にも下限がある(9)。
所要の抵抗係数とするためには, 抵抗の大きい 1 枚の金網を用いるよりも，抵抗の小さい $2 \sim 3$ 枚 の金網を用いた方が効果的である。

$2 \cdot 5$ 偏流部偏流部に備える案内羽根に厚 肉の翼形を採用すれば，翼間に形成される部分流 路がディフューザの作用をする結果, 各翼の後流 が長大になる。したがって近年は薄板を円弧に曲 げ，その前緑および後縁に短い直線部分を備えた 薄翼を等間隔に多数配置することが行われる ${ }^{(20)}$. 設計にさいしては，上下の根部にディスタンス・ ピースをはさむことにより, 案内羽根の位置を正 確に取付ける注意が必要である ${ }^{(6)}$.

$2 \cdot 6$ 測定部 測定部を開放形とすれば，自由 噴流の境界面に発生する乱れが測定部における低 乱流の実現を妨げるから，測定部は密閉形とする 必要がある ${ }^{(1)}$ 。整流部に同一の抵抗係数の金網 $n$ 枚を用いたとき，測定部における乱れ強さの概略 值は，式（1）および（3）から

$$
\frac{U^{\prime}}{U_{0}}=\frac{1}{c}\left(\frac{\mu_{c}+2 \nu_{c}}{3}\right)^{1 / 2}\left(\frac{1}{1+K}\right)^{n / 2} \frac{U_{h}^{\prime}}{U_{h}}
$$

式（4）は，整流胴内における乱れの自然減衰およ び最終金網によって作り出される乱れを無視して いる。後者のため，有効に働く織金網の枚数には 上限があり，それ以上の枚数を整流部に用いても， 測定部の乱れ強さは隇少しないことに注意する必 
要がある(1)(2)(21).

$2 \cdot 7$ 風洞用軸流送風機低乱風洞において は, 軸流送風機の設計 ${ }^{(6)(22)}$ も重要である. 送風機と 測定部の流路面積比は約 2 が適当であり，ハブ比 は 0.5 ないし 0.6 が推奖される。送風機には前置 静翼を設け，軸方向流出形とするが，動翼の枚数 を $N$ とするとき, 前置静翼の枚数を $N, 3 N / 2$, $2 N$ としてはならない。なお部分負荷においても 旋回流を生じないように，対称翼形からなる後置 静翼を設ける。ケーシングおよび八ブは流線形と し，八ブの全長はその直径の 3 倍以上とする。動 翼より下流における流路面積の㹡大の割合は，全 頂角 $5^{\circ}$ の等洒円すいのそれを越えてはならない。

2.8 騒音対策 低乱風洞の測定部では,騒音 による空気振動が気流の乱れと同程度の大きさと なる ${ }^{(3)}$.このため風洞の一部に吸音材を使用する ことにより，風洞内の音圧レベルを下げることが 行われる(6). 以下に述べる実例では, 各偏流部のダ クト内面をウレタンフォームで内張りしてある.

\section{3. 建設された低乱風洞の特性}

上記方針で設計・製作された低乱風洞(1)(2)の諸 元を表 1 に，その形状を図 3 に示す。測定部は二

表 1 東北大学高速力学研究所低乱風洞諸元

\begin{tabular}{|c|c|}
\hline 式 & 単路回流形 \\
\hline 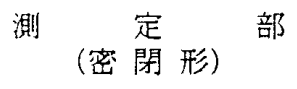 & $\begin{array}{l}\text { 長さ } 3.5 \mathrm{~m} \text {, 対辺距離 } 1.01 \mathrm{~m} \\
\text { 正八角形断面, 風速 } 5 \sim 70 \mathrm{~m} / \mathrm{s}\end{array}$ \\
\hline 送 & $\begin{array}{l}\text { 軸流 } 1 \text { 段（入口直径 } 1.54 \mathrm{~m}) \text {, } \\
\text { 風留 } 3180 \mathrm{~m}^{3} / \mathrm{min}, \\
\text { 全压 } 1.18 \mathrm{kPa}(120 \mathrm{mmAq})\end{array}$ \\
\hline 電 動 & $\begin{array}{l}\text { サイリスタ・レオナード方式, } \\
\text { 回転数 } 1100 \mathrm{rpm} \text {, 出力 } 95 \mathrm{~kW}\end{array}$ \\
\hline 整 流 部 金 網 & $\begin{array}{l}\text { ステンレス鋼製織金網 } 12 \text { 枚, } \\
20 \text { メッシュ, 線経 } 0.27 \mathrm{~mm} \text {, } \\
\text { 開口面積比 } 0.62\end{array}$ \\
\hline 八 = 力 厶 & $\begin{array}{l}\text { アルミニウム・ハニカム, } \\
\text { 対辺距﨎 } 19 \mathrm{~mm} \\
\text { 正六角形断面, 長さ } 150 \mathrm{~mm}\end{array}$ \\
\hline ノズル絞り比 & 12.0 \\
\hline $\begin{array}{l}\text { 第 } 1 \text { ディフューザ } \\
\text { 第 } 2 \text { ディフューザ }\end{array}$ & $\begin{array}{l}\text { 面積比 } 2.32 \text {, 頂角 } 5^{\circ} \\
\text { 面積比 } 2.98 \text {, 頂角 } 4^{\circ} 25^{\prime}\end{array}$ \\
\hline 第 1 , 第 2 偏流部 & 羽根枚数 23 枚, 弦長 $364 \mathrm{~mm}$ \\
\hline 第 3 , 第 4 偏流部 & 羽根枚数 33 枚, 弦長 $442 \mathrm{~mm}$ \\
\hline 広角度ディフューザ & $\begin{array}{l}\text { 面積比 } 1.73 \text {, 頂角 } 44^{\circ} 46^{\prime} \\
\text { ステンレス鎆彆織金網 } 3 \text { 枚 }\end{array}$ \\
\hline
\end{tabular}

次流れ(23)を生じないように正八角形断面とし，ま た流路軸方向の静圧こう配をわずかにするためフ イリットを設けてある。なお，测定部は開放形に 交換可能である。

$3 \cdot 1$ 測定部 測定部基準位置風軸中心上の 乱れ強さの主流方向成分 $\sqrt{u^{\prime 2}} / U_{0}$ を, 測定部風 速 $U_{0}$ に対し図 4 に示す。実線はトリップワイヤ を設けない場合で，風速 $25 \mathrm{~m} / \mathrm{s}$ 付近に境界層遷

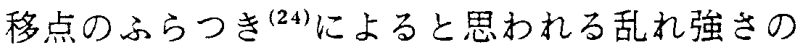
極大值が観察された。これを除くため本風洞には 直径 $0.75 \mathrm{~mm}$ のトリップワイヤが収縮ノズル壁 面に取付けられており，その結果，図中に示すよ うに風速 $U_{0}$ が $18 \mathrm{~m} / \mathrm{s}$ から $53 \mathrm{~m} / \mathrm{s}$ の範进にわた り, $\sqrt{\overline{u^{\prime 2}}} / U_{0}$ は $0.02 \%$ 以下となっている.図 5 は 測定部の風速分布で，風速分布の一様性は非常に 良好である。ここに図5以下はいずれも下流から

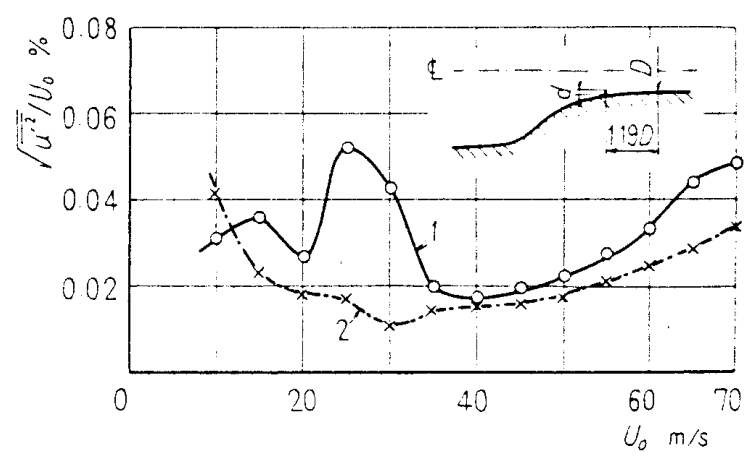

$1 ：$ トップワイヤなし, $2: d=0.75 \mathrm{~mm}$

図 4 測定部基準位置における気流の乱れ強さ

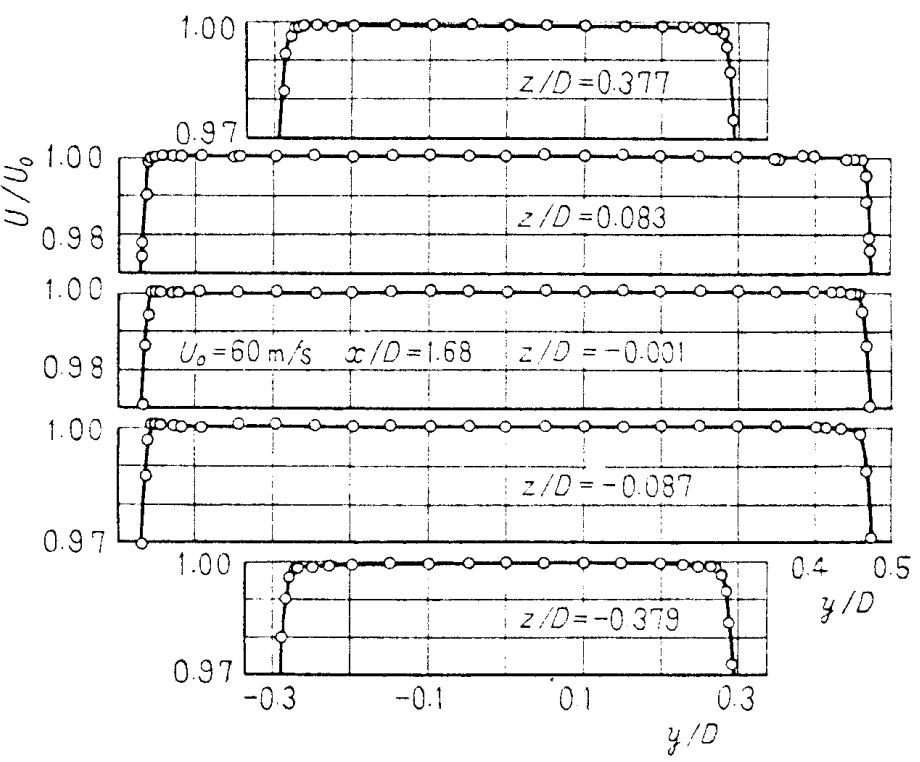

図 5 密閉形測定部の風速行布 
上流を見た図で,座標は右手系であり， $x$ 㹥流路軸 方向, $y>0$ 法回流す万流路の外側方向, $z>0$ は鉛 直上方に対応する。 $D$ は流路の対辺距離である。 図 6 に測定部における乱れ強さの 3 成分の分布を 示す。乱強さは，側壁付近を除きほほ一様な分 布である。側壁境界層の精密測定の結果 ${ }^{(2)}$ によれ ば，か上うな低乱風洞においては，気流の乱れ強 さが一䇐流における値と一致するまでに必要な側 壁からの距離流, 速度境界層の厚さの約 6 倍であ る。

\section{$3 \cdot 2$ 風洞各部風洞各断面の風速分布およ} び乱れ強さ分布の測定は, 総計 13 箇所の断面につ いて，流路中心軸を含む水平面内（整流部におい ては中心軸より $0.056 \mathrm{D}$ 上方の水平面内）で行わ 机た ${ }^{(2)}$. 以下，風洞の作動状況を示す代表的な例を 揭げる。

$3 \cdot 2 \cdot 1$ 整流部 図 7 は, $U_{m}$ を断面の平均風 速として，広角度ディフューザ出口の風速分布を 示す。 $V, W$ 成分に流路の拉大の影響が認められ る。このときの乱れ強さは，横断面についての平 均值で $1.6 \%$ である。図 8 汸八二カ厶下流（セル 出口から $8.4 d$ 下流, $d$ はセルの対辺距離)の風速 分布拉よび乱机強さの主流方向成分の分布で，八

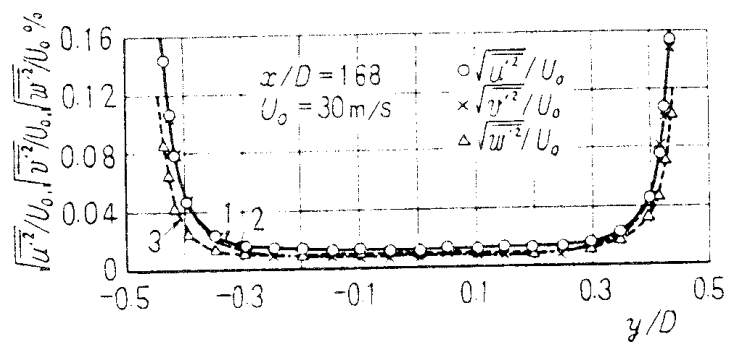

$1: \sqrt{u^{\prime 2}} / U_{0}, 2: \sqrt{\bar{U}^{\prime 2}} / U_{0}, 3: \sqrt{\overline{w^{\prime 2}}} / U_{0}$

図 6 密閉形測定部に㧍訬子気流乱机の 3 方向成分 の分布

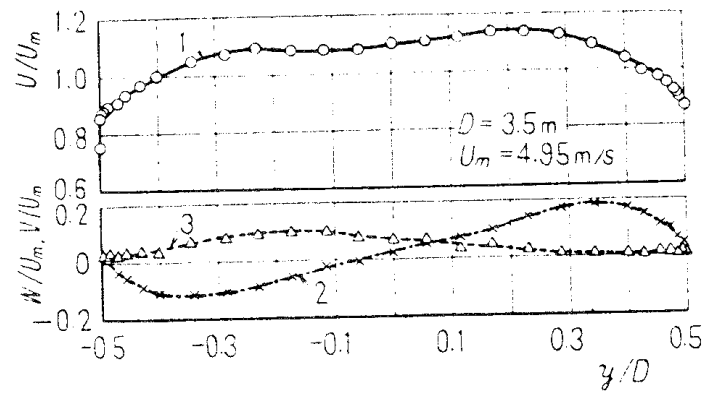

$1: U / U_{m}, 2: V / U_{m}, 3: W / U_{m}$

园 7 広角度ディフューザ出口における水平面内 の風速分而
二力么注 $V, W$ 成分を減少させ, 流れを軸方向に 向けるのに役立つが，八二力ム自身骀強い乱れを 発生する。つぎに本風洞に用いた 12 枚の整流部金 網の下流では風速分布は一様となり，また乱れ強 さ注減衰して，断面にわたり $0.24 \%$ となる住1）。

$3 \cdot 2 \cdot 2$ その他の断面 第 1 ディフューザ出 口の風速分布および乱れ強さ分布を図 9 に示す. 第1ディフニーザ内の流机はきわめて良好である ことが結論される。な扮，ディフニーザに治う正 の圧力こう配のため，境界層内の乱れ強さの極大 值は壁からかなり離れた位置に生じている。図 10 は送風機入口の風速分布拉よび乱強さ分布で, 流路を貫通する回転軸の後方で強い乱れが発生 し，また回転軸の近傍では軸の回転（下流から見 て時計まわり）の影響が速度分布および乱強さ 分布に認められる。つぎに送風機八ブの後流は第 2 ディフューザ入口のみならず出口でもめいりょ うに認められ，また，送風機によって生じた弱い 旋回流は，第 2 ディフューザ内で消隇している。 第 2 ディフューザ内の乱れ強さは，入口中央部で 約 $7 \%$,出口では場所により $9 \%$ から $13 \%$ に達す る。この強い乱机，第 $3 ，$ 第 4 偏流部を経て広 角度ディフューザ入口に至る間にかなり自然減衰
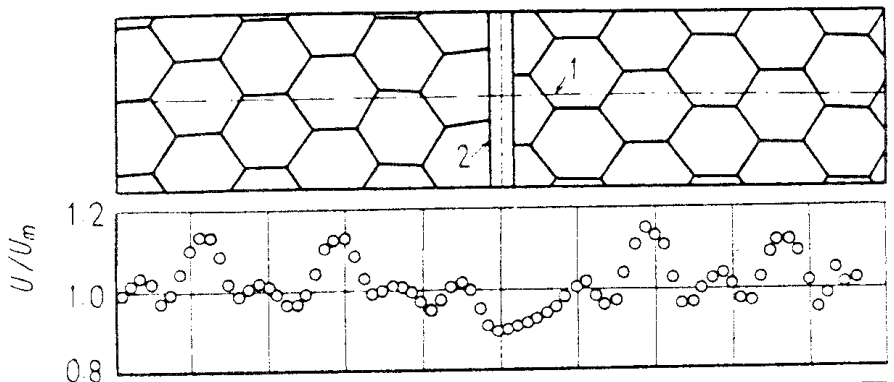

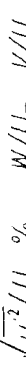

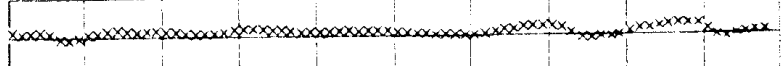

$-0$

$\stackrel{s}{s}$

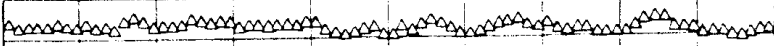

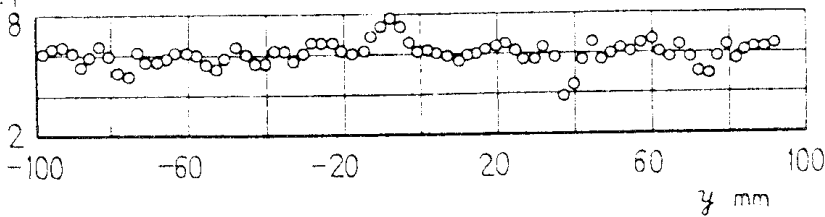

1：トラバース線, 2 : 補強板

闵 8 八二カ厶下流の風速分布㧍上び乱れ強さ分布。 $\left(U_{m}=4.94 \mathrm{~m} / \mathrm{s}\right)$

(注 1) 式(1)に上れば8枚の金網を用いた場合に相当する。し たがって、乱れ强さの大部分は鼠終金網自身から発生す る乱れによるものと考えられる。 
する.図 11 に第 4 偏流部案内羽根列下流の風速分 布と, 乱れ強さの主流方向成分の分布（トラバー ス面は流路軸に直角）を示す。送風機ハブの後流 は依然としてめいりょうであり，各案内羽根の後 流は弦長の約 2 倍下流まで認められる。送風機八
ブの後流は，図７に示すように広角度ディフュー ザの出口でほとんど消滅している。なお，上記風 洞のパワー係数は, 測定部風速 25〜 $70 \mathrm{~m} / \mathrm{s}$ にお いて 0.57〜0.44であった。

$3 \cdot 3$ 計測方法 低乱流の計測では, 熱線流速

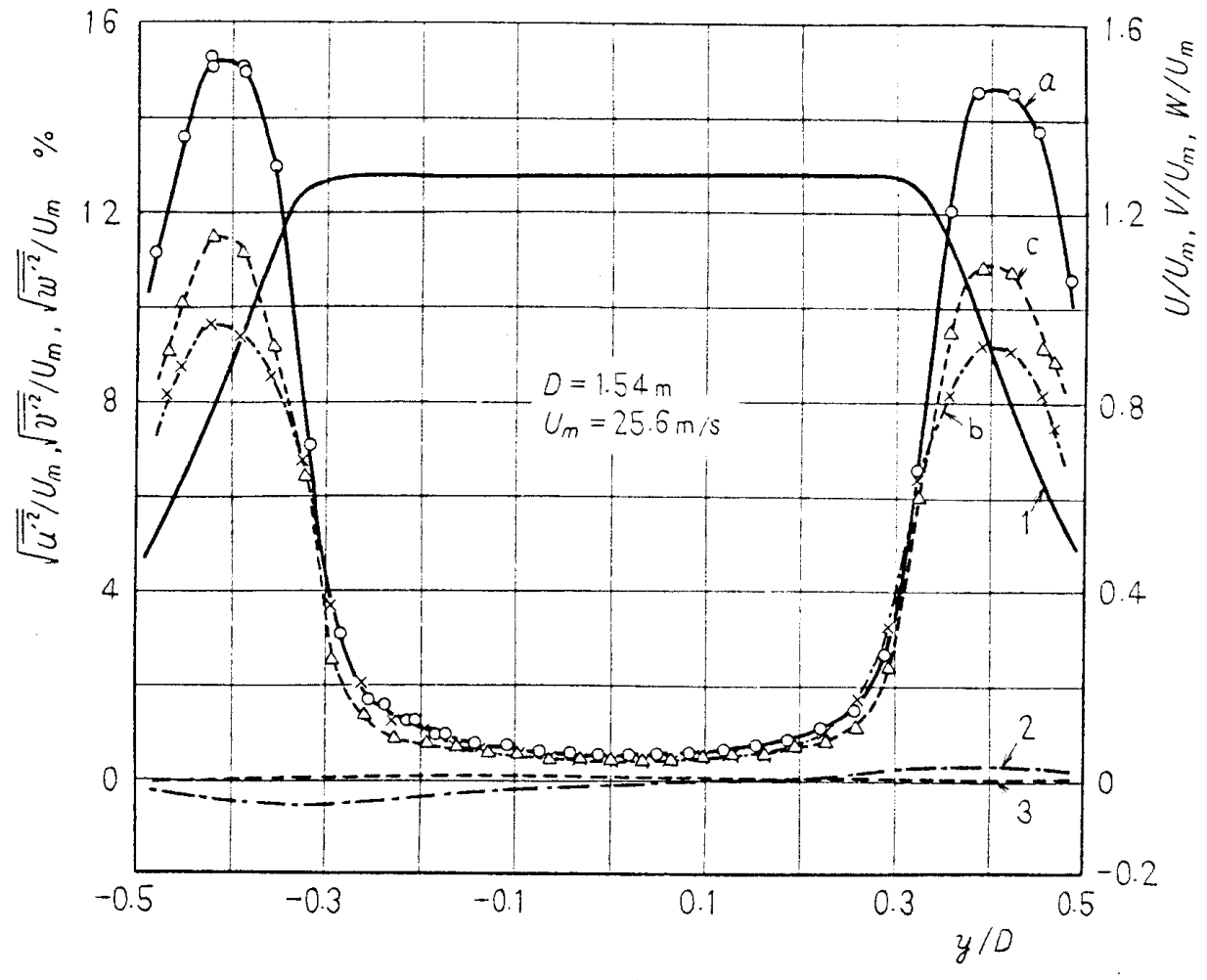

$1: U / U_{m}, 2: V / U_{m}, 3: W / U_{m}$

$$
\text { a }: \sqrt{\overline{u^{\prime 2}}} / U_{m} \quad \text { b }: \sqrt{\overline{v^{\prime 2}}} / U_{m} \quad \text { c }: \sqrt{\overline{w^{\prime 2}}} / U_{m}
$$

図 9 第 1 ディフューザ出口における水平面内の風速分布および乱机強さ分布

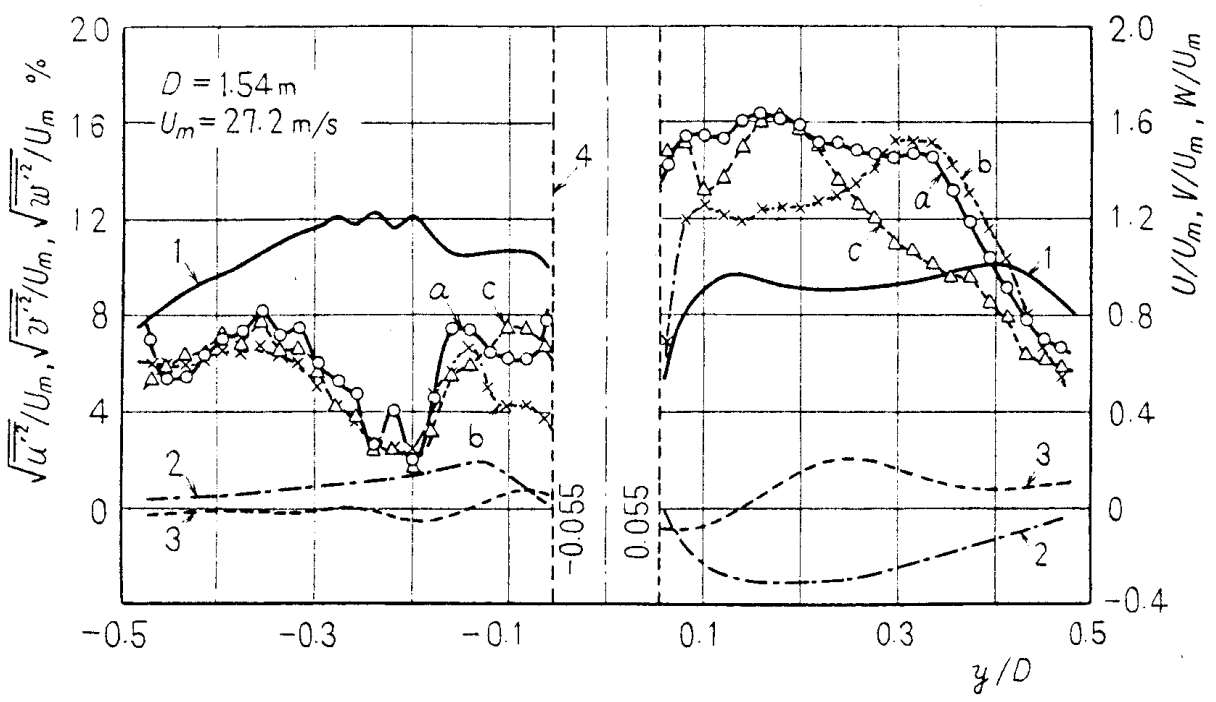

1:U/Um $, 2: V / U_{m}, 3: W / U_{m}, 4:$ 送風機主軸 a $: \sqrt{\overline{u^{\prime 2}}} / U_{m}, \mathrm{~b}: \sqrt{\overline{v^{\prime 2}}} / U_{m}, \mathrm{c}: \sqrt{\overline{w^{\prime 2}}} / U_{m}$

図 10 送風㙨入口に㧍ける水平面内の風速分布おょび乱れ強さ分布 


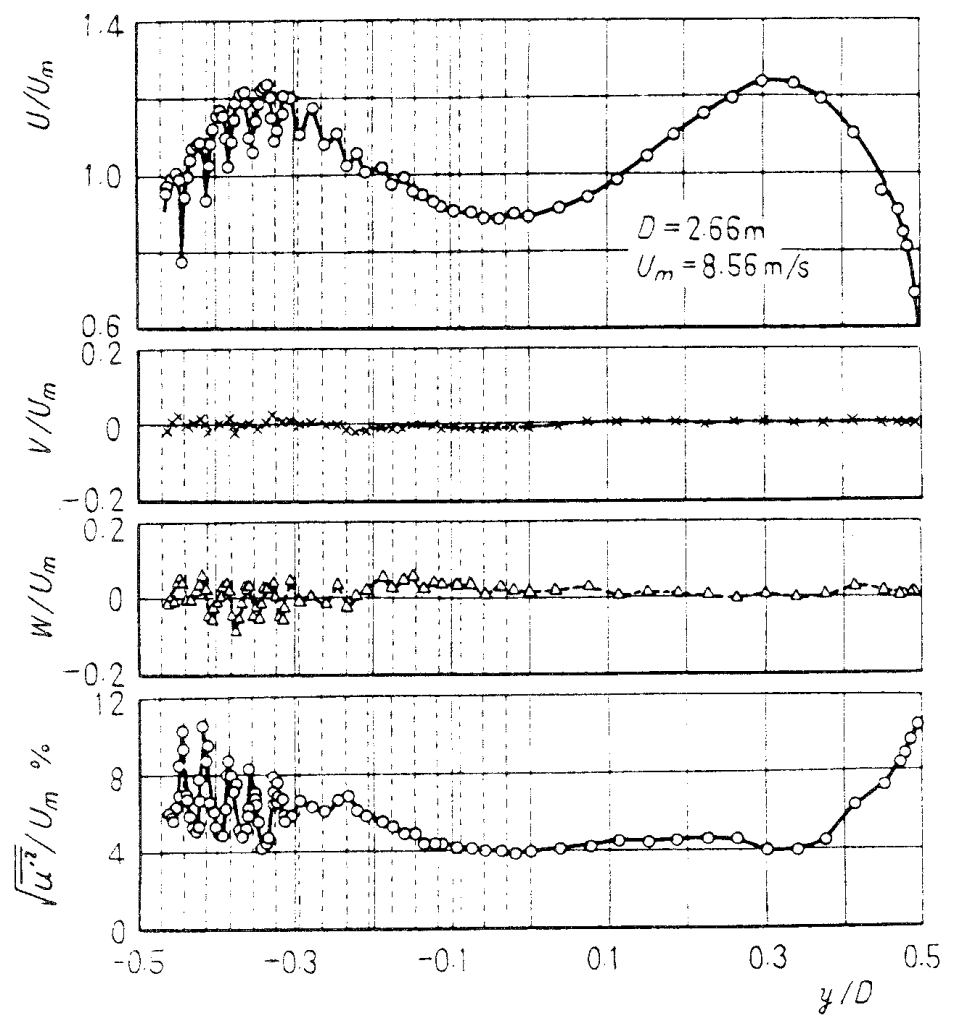

図 11 第 4 偏流部の案内羽根列下流における水平面 内の風速分布および乱れ強さ分布

計のノイズが低いことが必要である。本低乱風洞 の測定部に扮ける気流の乱れは, 風速 $30 \mathrm{~m} / \mathrm{s}$ に おいて $200 \mathrm{~Hz}$ 程度以下の周波数範囲にあり，使 用した熱線流速計に対するノイズ補正の大きさ は，乱れ強さ $0.02 \%$ \% $10 \%$ 前後であった。また 長時間にわたるトラバースでは, 風洞内気流の温 度変化が測定值に影響を及沽すため, 温度補償付 き熱線プローブを使用している，なお，広範囲に わたる気流乱れの影響を解明する目的に対して は, 本風洞には数枚の乱れ格子が用意されている.

\section{4.おわりに}

本低乱風洞は，現在，境界層の乱流遷移の研究 や，乱れ格子を使用して乱れ強さを広範囲に制御 した気流を必要とする研究の浪か, 学内の共同利 用設備として，気象・海洋物理・土木・建築など 広い分野の実験に使用されている。

なお，風洞内の代表的各断面の風速分布を測定 した例は，かつてイギリス RAE $4 \mathrm{ft} \times 3 \mathrm{ft}$ 低乱風
洞についてなされた記録(25)が存在するが，風 洞の形状が既に古く，しかも乱れ強さ分布の 測定はなされていない，本稿で述べた風洞設 計方法と測定結果が, 今後の低乱風洞の設計 に役立てば幸いである。

(原稿受付 昭和 60 年 10 月 2 日)

\section{文献}

（1）伊藤・ほか 13 名，東北大学高速力学研究所報告，44395 (昭 55)，93

（2）伊藤 - 活加 6 名，東北大学高速力学研究所報告。34450 (昭 60)，67.

(3) Dryden, H.L. and Schubauer, G.B., J. Aeronaut. Sci., 14-4 (1947), 221.

(4) Wieghardt, K.E.G., Aeronaut. Q., 4-2 (1953), 186.

(5) Taylor, G.I. and Batchelor, G.K., Q. J.Mech. Appl. Math., 2-1 (1949), 1.

(6) Bradshaw, P. and Pankhurst, R.C., Progress in Aeronautical Sciences, 5 (1964), 1, Pergamon Press.

(7) Ower, E. and Pankhurst, R.C., The Measurement of Air Flow, (1966), 197, Pergamon Press.

(8) Pankhurst, R.C. and Holder, D.W., Wind-Tunnel Technique, (1952), 84, Sir Isaac Pitman \& Sons.

(9) Mehta, R.D. and Bradshaw, P., Aeronaut. J., 83827 (1979), 443.

(10) Batchelor, G.K. and Proudman, I., Q. J.Mech. Appl. Math., 7-1 (1954), 83.

(11) Prandtl, L., Handbuch der Experimentalphysik, 4-2 (1932), 65. Akad. Verl.

(12) Batchelor, G.K., The Theory of Homogeneous Turbulence, (1956), 74. Cambridge Univ. Press.

(13) Hussain, A.K.M.F. and Ramjee, V., Trans. ASME, Ser. I. $98-1$ (1976), 58.

(14) Rouse, H. and Hassan, M.M., Mech. Eng., 71-3 (1949), 213.

(15) Morel, T., Trans. ASME, Ser. I, 97-2 (1975), 225.

(16) Thwaites, B., Aeronaut. Res. Council, Rep. \& Mem. 2278 (1946), 2279.

（17）小林，東北大学高速力学研究所報告， 46-400（昭 56），17,

(18) MacPhail, D.C., ほか2 名, Aeronaut. Res. Council, Rep. \& Mem.. 2424 (1945).

(19) Pope, A. and Harper, J. J., Low-Speed Wind Tunnel Testing. (1966), 41, John Wiley \& Sons.

(20) Salter, C., Aeronaut. Res. Council, Rep. \& Mem., 2469 (1946).

（21）小浜・渒加 2 名，東北大学高速力学研究所報告，48-422 (昭 57), 119.

(22) Bradshaw, P. and Hellens, G.E., Aeronaut. Res. Council, Rep. \& Mem., 3437 (1964).

(23) Bansod, P. and Bradshaw, P., Aeronaut. Q., 23-2 (1972), 131.

(24) Schuh, H. and Winter, K.G., Aeronaut. Res. Council, Rep. \& Mem., 2905 (1951).

(25) Squire, H.B. and Winter, K.G., Aeronaut. Res. Council, Rep. \& Mem., 2690 (1948). 